\title{
Determinan Status Kesehatan Balita di Provinsi Nusa Tenggara Timur Tahun 2019
}

\author{
(Determinants of Baby's Health Status in East Nusa Tenggara Province in 2019) \\ Muh. Reza Agung Wirawan ${ }^{*}$, Siti Muchlisoh ${ }^{2}$ \\ ${ }^{1,2}$ Politeknik Statistika STIS \\ BTN BBP Agang Je'ne, Kel. Empoang, Kec. Binamu, Kab. Jeneponto, Sulawesi Selatan \\ E-mail: 111810434@stis.ac.id
}

\begin{abstract}
ABSTRAK
Kesehatan merupakan hak dasar bagi setiap manusia. Balita merupakan kelompok penduduk yang paling rentan mengalami masalah kesehatan. Provinsi Nusa Tenggara Timur merupakan salah satu provinsi dengan derajat kesehatan balita yang rendah. Dalam kurun waktu 3 tahun, yaitu 2017-2019 persentase penduduk balita atau bayi usia 0-4 tahun yang mempunyai keluhan kesehatan mengalami peningkatan dari 47,69 persen pada tahun 2017 menjadi 52,68 persen pada tahun 2019. Tujuan penelitian ini untuk mengidentifikasi gambaran umum terkait status kesehatan balita, variabelvariabel yang mempengaruhinya serta kecenderungan variabel-variabel tersebut terhadap status kesehatan balita di Nusa Tenggara Timur tahun 2019. Data yang digunakan adalah raw data Survei Sosial Ekonomi Nasional Modul Kesehatan dan Perumahan (Susenas MKP) tahun 2019 yang diperoleh dari Badan Pusat Statistik. Metode analisis yang digunakan adalah regresi logistik biner. Hasil analisis menunjukkan bahwa umur balita, kesehatan ibu dan akses sanitasi berpengaruh signifikan terhadap status kesehatan balita. Balita dengan karakteristik berusia kurang dari dua tahun yang memiliki ibu tidak sehat serta memiliki tempat tinggal dengan akses sanitasi yang tidak layak memiliki kecenderungan yang lebih besar untuk tidak sehat.
\end{abstract}

Kata kunci: status kesehatan, balita, regresi logistik biner

\begin{abstract}
Health is a fundamental right for every human being. Babies are the most vulnerable group of the population to have health problems. East Nusa Tenggara Province is one of provinces with low levels of babies' health. Within three years, 2017-2019, the percentage of population aged 0-4 years who had health complaint increased from 47,69 percent in 2017 to 52,31 percent in 2019. The purpose of this research is to identify basic information about baby's health status, to identify variables that affect baby's health status and the tendency those variables to baby's health status in Nusa Tenggara Timur Province in 2019. The data used in this research is raw data from National Socio-Economics Survey Housing and Health Module (Susenas MKP) in 2019 which is obtained from Badan Pusat Statistik. The analytical method used logistic binary regression. The results of research show that baby's age, mother's education level, mother's employment, mother's health and sanitation access significantly affect baby's health status. Babies who aged under two years, had unhealthy mothers and having bad sanitation access are riskier to get unhealthy.
\end{abstract}

Keywords: health status, baby, binary logistic regression

\section{PENDAHULUAN}

Salah satu tujuan yang hendak dicapai pada tahun 2030 sebagai Tujuan Pembangunan Berkelanjutan (TPB) atau dikenal juga dengan istilah Sustainable Development Goals (SDGs) adalah menjamin kehidupan yang sehat untuk seluruh penduduk. Kesehatan merupakan hak dasar bagi setiap manusia. Kesehatan atau sehat dapat diartikan sebagai keadaan sejahtera fisik, psikis dan sosial yang memungkinkan seseorang untuk melakukan hal produktif secara ekonomi maupun sosial (Notoatmodjo, 2008). Kehidupan yang sehat menjadi sangat penting mengingat segala aktivitas yang kita lakukan sehari-hari dapat terganggu apabila kesehatan kita juga terganggu. Hal tersebut dapat berdampak pada tidak bisanya seseorang beraktivitas sehari-hari seperti bekerja, bersekolah ataupun mengerjakan hal-hal penting lainnya. Bahkan dampak yang ditimbulkan dari kesehatan yang terganggu dapat lebih buruk hingga menyebabkan kematian.

Menurut Soekirman (2000) dalam Fitriyani et al. (2008), kelompok penduduk yang merupakan kelompok yang paling rentan kesehatannya terhadap risiko terkena penyakit adalah bayi atau anak di bawah usia 5 tahun. Behrman et al. (1999) mengatakan bahwa masalah kesehatan pada bayi berbeda dengan orang dewasa dan respon bayi ketika sakit dan stress berbeda-beda sesuai dengan usianya. Kesehatan yang dimiliki 
oleh balita sangat ditentukan oleh orang-orang di sekitarnya, terutama orang tuanya dan juga kondisi lingkungan di sekitarnya.

Masa balita merupakan periode atau tahun-tahun pertama kehidupan manusia. Masa tersebut merupakan masa penting dan kritis. Masa yang penting karena pada periode inilah organ-organ penting akan berkembang, terutama otak dan akan menentukan kualitas hidupnya dimasa mendatang. Selain itu, masa balita juga merupakan masa krisis karena pada masa ini bayi akan sangat peka terhadap lingkungannya. Masa balita digolongkan sebagai tahapan perkembangan yang sangat berpotensi mempunyai masalah kesehatan. Dibandingkan dengan orang dewasa, balita lebih rentan terhadap penyakit. Penyakit-penyakit yang sering kali dialami oleh balita antara lain diare, ISPA, pneumonia, DBD, demam atau cacingan. Beberapa penyakit tersebut mungkin dianggap ringan dan biasa, tetapi dampaknya sangat berbahaya, bahkan dapat menyebabkan kematian jika tidak ditangani secara lanjut. Balita yang memiliki masalah kesehatan dan gizi yang buruk maka balita tersebut dapat mengalami kerusakan pada otak yang bersifat permanen atau tidak dapat disembuhkan kembali.

Permasalahan kesehatan bayi masih menjadi salah satu masalah kesehatan di beberapa negara, termasuk Indonesia. Berdasarkan hasil SDKI 2017, angka kematian bayi (AKB) di Indonesia adalah sebesar 24 kematian setiap 1.000 kelahiran hidup. Angka ini menurun dibandingkan dengan tahun 2012. Adapun angka kematian balita (AKaBa) di Indonesia adalah sebesar 32 kematian setiap 1.000 kelahiran hidup. Angka tersebut mengalami penurunan jika dibandingkan AKaba tahun 2012, yaitu sebesar 40 setiap 1.000 kelahiran hidup (Badan Pusat Statistik, 2019). Angka tersebut masih cukup tinggi dan masih jauh dari target pembangunan berkelanjutan (Sustainable Development Goals/SDGs), yaitu sebesar 25 kematian setiap 1.000 kelahiran hidup.

Nusa Tenggara Timur merupakan salah satu Provinsi di Indonesia yang derajat kesehatan balitanya masih rendah. Hal ini dapat dilihat dari hasil Riskesdas 2018 dimana prevalensi stunting pada balita di Nusa Tenggara Timur merupakan yang tertinggi di Indonesia, yaitu mencapai 42,7 persen. Sangat tinggi apabila dibandingkan dengan prevalensi stunting nasional, yaitu sebesar 30,8 persen. Demikian pula pada indikator kesehatan bayi lainnya, seperti persentase balita gizi buruk, yaitu sebesar 7,3 persen dan persentase balita wasting, yaitu sebesar 13,0 persen lebih tinggi dibandingkan dengan angka nasional yang masing-masing sebesar 3,9 persen dan 10,2 persen.

Indikator lainnya yang sering digunakan untuk mengukur tingkat kesehatan balita adalah keluhan kesehatan pada balita. Keluhan kesehatan pada balita mengindikasikan bahwa balita mengalami gangguan kesehatan yang dapat disebabkan oleh suatu penyakit, baik itu bersifat akut maupun kronis, kecelakaan, kriminalitas atau gangguan fisik atau psikis lainnya (Badan Pusat Statistik, 2018). Keluhan kesehatan ini dapat berdampak serius, seperti adanya komplikasi penyakit apabila penanganannya lambat dan tidak tepat. Indikator keluhan kesehatan ini selanjutnya disebut sebagai morbiditas apabila keluhan kesehatan yang dialami mengganggu aktivitas normal sehari-hari.

Berdasarkan data Badan Pusat Statistik pada tahun 2019, persentase penduduk bayi dibawah usia 5 tahun yang mempunyai keluhan kesehatan di Nusa Tenggara Timur adalah sebesar 52,68 persen. Angka tersebut lebih tinggi dibandingkan nasional, yaitu sebesar 47,87. Dalam kurun waktu 3 tahun, yaitu $2017-$ 2019 persentase penduduk balita atau bayi usia 0-4 tahun yang mempunyai keluhan kesehatan mengalami tren peningkatan dari 47,69 persen pada tahun 2017 menjadi 52,68 persen pada tahun 2019. Hasil Riskesdas 2018 juga menunjukkan keluhan atau penyakit yang kerap dialami oleh balita, seperti ISPA, pneumonia dan diare, prevalensinya cukup tinggi di Nusa Tenggara Timur. Berdasarkan indikator-indikator tersebut menunjukkan bahwa kualitas kesehatan balita di Provinsi Nusa Tenggara Timur masih rendah.

Seorang balita yang memiliki gangguan kesehatan atau sakit dapat disebabkan oleh banyak faktor. Blum (1969) dalam Riyadi (2016) mengatakan bahwa kesehatan seseorang dipengaruhi oleh kondisi lingkungan, perilaku hidup sehat, pelayanan kesehatan dan faktor keturunan. Menurut Behrman et al. (1999), pengaruh sosial atau lingkungan mempunyai dampak besar pada kesehatan anak dan keluarganya. Eliana dan Sumiati, S. (2016) juga mengatakan bahwa konstruksi hunian atau rumah dan lingkungan yang tidak memenuhi syarat kesehatan adalah salah satu faktor risiko sumber terjadinya berbagai jenis penyakit.

Nusantari (2016) menyimpulkan bahwa kesehatan baduta dalam rumah tangga miskin di Indonesia dipengaruhi oleh faktor keluarga, yaitu pemberian ASI dan MP-ASI serta faktor lingkungan, yaitu sumber air minum utama dan fasilitas pembuangan air besar. Sementara itu, faktor keluarga lainnya, seperti imunisasi dasar lengkap, pendidikan ibu dan status bekerja ibu serta faktor lingkungan, seperti sumber air memasak dan sumber air mendi/mencuci tidak mempengaruhi kesehatan baduta secara signifikan.

Penelitian Shahraki et al. (2016) menunjukkan bahwa pekerjaan ibu, jumlah anggota keluarga dan kejadian kembar berpengaruh negatif terhadap kesehatan anaknya sedangkan pendidikan ibu berpengaruh positif. Suanta (2016) dalam penelitiannya mengungkapkan bahwa karakteristik sanitasi lingkungan tempat 
tinggal dan karakteristik sosioekonomi mempengaruhi status kejadian diare pada baduta di Provinsi Nusa Tenggara Timur.

Berdasarkan uraian di atas, tujuan dari penelitian ini, yaitu (1) mengidentifikasi variabel-variabel yang mempengaruhi status kesehatan balita di Provinsi Nusa Tenggara Timur tahun 2019 dan (2) mengidentifikasi kecenderungan status kesehatan balita di Provinsi Nusa Tenggara Timur tahun 2019.

\section{METODE}

Penelitian ini mencakup rumah tangga yang terdapat di Provinsi Nusa Tenggara Timur pada tahun 2019. Namun, rumah tangga yang dimaksud pada penelitian ini dibatasi pada rumah tangga dengan keberadaan balita yang memiliki ibu. Data yang digunakan pada penelitian adalah data sekunder berupa raw data Survei Sosial Ekonomi Nasional Modul Kesehatan dan Perumahan (Susenas MKP) tahun 2019 yang diperoleh dari Badan Pusat Statistik.

Tabel 1. Variabel penelitian

\begin{tabular}{|c|c|c|c|c|}
\hline No. & Variabel & Kategori & Nilai Dummy & Notasi \\
\hline \multirow{2}{*}{1.} & \multirow{2}{*}{ Status kesehatan balita } & Sehat & 0 & \multirow{2}{*}{$\mathrm{Y}$} \\
\hline & & Tidak sehat & 1 & \\
\hline \multirow{2}{*}{2.} & \multirow{2}{*}{ Umur balita } & $\geq 2$ tahun & 0 & \multirow{2}{*}{ D1 } \\
\hline & & $<2$ tahun & 1 & \\
\hline \multirow{2}{*}{3.} & \multirow{2}{*}{ Tingkat pendidikan ibu } & Tamat SMA ke atas & 0 & \multirow{2}{*}{ D2 } \\
\hline & & Tamat SMP ke bawah & 1 & \\
\hline \multirow{2}{*}{4.} & \multirow{2}{*}{ Status pekerjaan ibu } & Bekerja & 0 & \multirow{2}{*}{ D3 } \\
\hline & & Tidak bekerja & 1 & \\
\hline \multirow{2}{*}{5.} & \multirow{2}{*}{ Kesehatan ibu } & Sehat & 0 & \multirow{2}{*}{ D4 } \\
\hline & & Tidak sehat & 1 & \\
\hline \multirow{2}{*}{6.} & \multirow{2}{*}{ Akses sanitasi } & Layak & 0 & \multirow{2}{*}{ D5 } \\
\hline & & Tidak layak & 1 & \\
\hline \multirow{2}{*}{7.} & \multirow{2}{*}{ Akses air minum } & Layak & 0 & \multirow{2}{*}{ D6 } \\
\hline & & Tidak layak & 1 & \\
\hline \multirow{2}{*}{8.} & \multirow{2}{*}{ Jenis lantai tempat tinggal } & Layak & 0 & \multirow{2}{*}{ D7 } \\
\hline & & Tidak layak & 1 & \\
\hline \multirow{2}{*}{9.} & \multirow{2}{*}{ Kebiasaan merokok ART } & Tidak merokok & 0 & \multirow{2}{*}{ D8 } \\
\hline & & Merokok & 1 & \\
\hline
\end{tabular}

Dalam penelitian ini, metode analisis yang digunakan terdiri dari analisis deskriptif dan analisis inferensia. Analisis deskriptif digunakan dengan tujuan agar dapat memperoleh gambaran secara umum karakteristik mengenai status kesehatan balita di provinsi Nusa Tenggara Timur tahun 2019 berdasarkan karakteristik individu balita, ibu dan lingkungan tempat tinggal. Analisis inferensia digunakan untuk mengetahui variabel independen yang berpengaruh secara signifikan terhadap status kesehatan balita di Nusa Tenggara Timur tahun 2019. Analisis inferensia yang digunakan adalah analisis regresi logistik biner dengan $\alpha=5$ persen. Analisis regresi logistik biner merupakan metode regresi yang digunakan untuk menganalisis hubungan variabel dependen dengan dua kategorik dan variabel independen (Hosmer, et al., 2013).

Tahapan analisis diawali dengan pembentukan model persamaan regresi logistik biner dengan metode Maximum Likelihood Estimate (MLE). Model regresi logistik biner untuk menggambarkan status kesehatan balita adalah sebagai berikut.

$$
\hat{g}(x)=\hat{\beta}_{0}+\hat{\beta}_{1} D_{1}+\hat{\beta}_{2} D_{2}+\hat{\beta}_{3} D_{3}+\hat{\beta}_{4} D_{4}+\hat{\beta}_{5} D_{5}+\hat{\beta}_{6} D_{6}+\hat{\beta}_{7} D_{7}+\hat{\beta}_{8} D_{8}
$$

Kemudian dilakukan beberapa pengujian parameter model sebagai berikut.

\section{a) Uji Simultan}

Uji simultan dilakukan untuk mengetahui apakah terdapat pengaruh signifikan variabel independen terhadap status kesehatan balita secara bersama-sama atau apakah terdapat minimal 1 variabel independen yang berpengaruh secara signifikan di dalam model dengan menggunakan statistik uji Likelihood Ratio Test $\left(G^{2}\right)$. Hipotesis pada pengujian simultan ini, yaitu :

$\mathrm{H}_{0}: \beta_{1}=\beta_{2}=\cdots=\beta_{8}=0$ (tidak ada pengaruh variabel independen terhadap status kesehatan balita secara simultan) 
$\mathrm{H}_{1}$ : Minimal ada satu $\beta_{j} \neq 0$ (minimal ada satu variabel independen yang berpengaruh terhadap status kesehatan balita) dengan $\mathrm{j}=1,2, \ldots, 8$.

Statistik uji :

$G=-2 \ln \left(\frac{L_{0}}{L_{1}}\right) \sim \chi_{(8)}^{2}$

Keterangan :

$L_{0}$ : nilai likelihood tanpa variabel independen

$L_{1}$ : nilai likelihood dengan variabel independen

Pengujian ini akan menghasilkan keputusan tolak $\mathrm{H}_{0}$ apabila nilai $G^{2}>\chi_{(0,05 ; 8)}^{2}=15,507$ atau $p$ value $<0,05$. Apabila $\mathrm{H}_{0}$ ditolak maka dapat diartikan bahwa terdapat minimal satu variabel independen yang berpengaruh secara signifikan terhadap status kesehatan balita di Nusa Tenggara Timur tahun 2019.

b) Uji Parsial

Uji parsial dilakukan untuk mengetahui pengaruh masing-masing variabel independen terhadap status kesehatan balita dengan menggunakan statistik uji Wald $(W)$. Hipotesis yang diuji adalah sebagai berikut.

$\mathrm{H}_{0}: \beta_{j}=0$, dengan $\mathrm{j}=1,2, \ldots, 8$.(variabel independen ke-j tidak berpengaruh signifikan terhadap status kesehatan balita)

$\mathrm{H}_{1}: \beta_{j} \neq 0$, dengan $\mathrm{j}=1,2, \ldots, 8$. (variabel independen ke-j berpengaruh signifikan terhadap status kesehatan balita)

Statistik uji :

$$
W=\left(\frac{\widehat{\beta}_{j}}{\operatorname{SE}\left(\widehat{\beta}_{j}\right)}\right)^{2} \sim \chi_{(1)}^{2}
$$

Pada tingkat signifikansi 5 persen, pengujian ini akan menghasilkan keputusan tolak $\mathrm{H}_{0}$ apabila nilai pengujian ini akan menghasilkan keputusan tolak $\mathrm{H}_{0}$ apabila nilai $W>\chi_{(0,05 ; 1)}^{2}=3,841$ atau $p$-value < 0,05 . Apabila $\mathrm{H}_{0}$ ditolak maka dapat diartikan bahwa variabel independen ke-j berpengaruh secara signifikan terhadap status kesehatan balita di Nusa Tenggara Timur tahun 2019.

c) Uji Kesesuaian Model

Tahapan dilanjutkan dengan pengujian kesesuaian model untuk mengetahui ketepatan model yang diperoleh dalam menggambarkan status kesehatan balita dengan menggunakan uji Hosmer-Lemeshow. Hipotesis uji Hosmer-Lemeshow adalah sebagai berikut.

$\mathrm{H}_{0}$ : Model fit

$\mathrm{H}_{1}$ : Model tidak fit

Statistik uji :

$\hat{C}=\sum_{k=1}^{g} \frac{\left(o_{k}-n_{k}^{\prime} \bar{\pi}_{k}\right)^{2}}{n_{k}^{\prime} \bar{\pi}_{k}\left(1-\bar{\pi}_{k}\right)} \sim \chi_{(g-2)}^{2}$

Keterangan :

g : banyak kelompok yang terbentuk dari tabel observasi dan harapan

$n_{k}^{\prime}:$ total subjek pada kelompok ke-k

$O_{k}:$ jumlah nilai dari variabel dependen kelompok ke-k

$\bar{\pi}_{k}$ : rata-rata estimasi peluang

Keputusan $\mathrm{H}_{0}$ akan gagal tolak apabila nilai $\hat{C} \leq \chi^{2}{ }_{(0,05 ; g-2)}$ atau $p$-value $\geq 0,05$. Apabila $\mathrm{H}_{0}$ gagal tolak, dapat diartikan bahwa model yang terbentuk adalah model fit atau model telah menggambarkan status kesehatan balita di Nusa Tenggara Timur tahun 2019 secara tepat.

Tahapan terakhir yang dilakukan adalah interpretasi koefisien regresi logistik biner dengan menggunakan nilai odds ratio pada nilai $\exp \left(\beta_{j}\right)$ untuk mengetahui kecenderungan status kesehatan balita.

\section{HASIL DAN PEMBAHASAN}

Persentase balita yang berstatus tidak sehat sangat tinggi di Nusa Tenggara Timur tahun 2019 hampir sama dibandingkan dengan balita berstatus sehat. Sebanyak persen balita 50,31 yang berstatus tidak sehat sedangkan 49,69 persen balita berstatus sehat. 


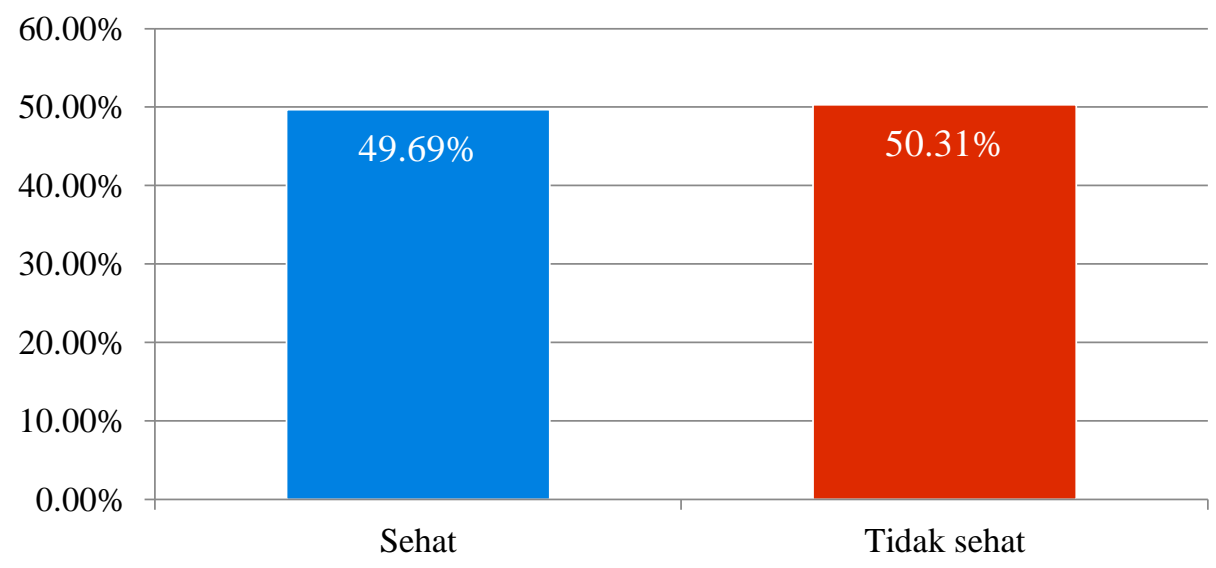

Sumber : Susenas MKP 2019 (diolah)

Gambar 5. Persentase status kesehatan balita di Nusa Tenggara Timur tahun 2019

Tabel 2. Karakteristik status kesehatan balita di Nusa Tenggara Timur Tahun 2019

\begin{tabular}{|c|c|c|c|c|}
\hline \multirow{2}{*}{ No. } & \multirow{2}{*}{ Variabel } & \multirow{2}{*}{ Kategori } & \multicolumn{2}{|c|}{ Status Kesehatan } \\
\hline & & & Sehat & Tidak Sehat \\
\hline \multirow{2}{*}{1.} & \multirow{2}{*}{ Umur balita } & $\geq 2$ tahun & $54.38 \%$ & $45.62 \%$ \\
\hline & & $<2$ tahun & $45.30 \%$ & $54.70 \%$ \\
\hline \multirow{2}{*}{2.} & \multirow{2}{*}{ Tingkat pendidikan ibu } & Tamat SMA ke atas & $46.50 \%$ & $53.50 \%$ \\
\hline & & Tamat SMP ke bawah & $51.50 \%$ & $48.50 \%$ \\
\hline \multirow{2}{*}{3.} & \multirow{2}{*}{ Status pekerjaan ibu } & Bekerja & $48.00 \%$ & $52.00 \%$ \\
\hline & & Tidak Bekerja & $51.76 \%$ & $48.24 \%$ \\
\hline \multirow[b]{2}{*}{4.} & \multirow[b]{2}{*}{ Kesehatan ibu } & Sehat & $56.13 \%$ & $43.87 \%$ \\
\hline & & Tidak sehat & $35.10 \%$ & $64.90 \%$ \\
\hline \multirow{2}{*}{5.} & \multirow{2}{*}{ Akses sanitasi } & Layak & $52.19 \%$ & $47.81 \%$ \\
\hline & & Tidak layak & $46.71 \%$ & $53.29 \%$ \\
\hline \multirow{2}{*}{6.} & \multirow{2}{*}{ Sumber air minum } & Bersih & $47.07 \%$ & $52.93 \%$ \\
\hline & & Tidak Bersih & $56.18 \%$ & $43.82 \%$ \\
\hline \multirow{2}{*}{7.} & \multirow{2}{*}{ Jenis lantai } & Layak & $48.04 \%$ & $51.96 \%$ \\
\hline & & Tidak layak & $56.28 \%$ & $43.72 \%$ \\
\hline \multirow{2}{*}{8.} & \multirow{2}{*}{ Kebiasaan merokok ART } & Tidak Merokok & $57.46 \%$ & $42.54 \%$ \\
\hline & & Merokok & $48.23 \%$ & $51.77 \%$ \\
\hline
\end{tabular}

Sumber : Susenas MKP 2019 (diolah)

Berdasarkan tabel di atas, dapat diketahui bahwa balita dengan karakteristik berumur kurang dari dua tahun yang memiliki ibu dengan tingkat pendidikan tamat SMA ke atas, bekerja dan tidak sehat serta memiliki lingkungan tempat tinggal dengan akses sanitasi tidak layak, sumber air minum bersih, lantai layak dan tinggal bersama ART yang memiliki kebiasaan merokok di dalam rumah lebih banyak yang berstatus tidak sehat.

\section{Pengujian Simultan}

Tabel 3. Hasil pengujian simultan

\begin{tabular}{ccc}
\hline Chi-square & df & p-value \\
\hline 58,804 & 8 & 0,000 \\
\hline Sumber: Susenas MKP 2019 (diolah)
\end{tabular}

Hasil pengujian simultan diperoleh nilai $G^{2}=58,804>\chi_{(0,05 ; 8)}^{2}=15,507$ dan $p$-value $=0,000<0,05$. Oleh karena itu, keputusan tolak $\mathrm{H}_{0}$. Maka dapat disimpulkan bahwa pada tingkat signifikansi 5 persen terdapat minimal satu variabel independen yang berpengaruh secara signifikan terhadap status kesehatan balita di provinsi Nusa Tenggara Timur tahun 2019.

\section{Pengujian Parsial}

Hasil pengujian parsial yang diperoleh adalah sebagai berikut. 
Tabel 4. Hasil pengujian parsial

\begin{tabular}{|c|c|c|c|c|}
\hline \multirow{2}{*}{\multicolumn{5}{|c|}{$\begin{array}{r}\text { Variabel } \\
\text { Umur balita }(<2 \text { tahun })^{*}\end{array}$}} \\
\hline & & & & \\
\hline$\geq 2$ tahun & 0,372 & 7,586 & 0,006 & 1,451 \\
\hline Tingkat pendidikan ibu $(\leq \mathrm{SMP})^{* *}$ & & & & \\
\hline$\geq$ SMA & $-0,258$ & 3,200 & 0,074 & 0,773 \\
\hline Status pekerjaan ibu (bekerja)** & & & & \\
\hline tidak bekerja & $-0,245$ & 3,232 & 0,072 & 0,782 \\
\hline Kesehatan ibu (sehat)* & & & & \\
\hline $\begin{array}{c}\text { tidak sehat } \\
\text { Akses sanitasi (layak)* }\end{array}$ & 0,881 & 36,757 & 0,000 & 2,414 \\
\hline $\begin{array}{l}\text { tidak layak } \\
\text { Sumber air minum (bersih) }\end{array}$ & 0,208 & 4,011 & 0,045 & 1,323 \\
\hline $\begin{array}{c}\text { tidak bersih } \\
\text { Jenis lantai (layak) }\end{array}$ & $-0,045$ & 0,098 & 0,760 & 0,956 \\
\hline $\begin{array}{l}\text { tidak layak } \\
\text { Kebiasaan merokok ART (merokok) }\end{array}$ & $-0,174$ & 1,094 & 0,296 & 0,840 \\
\hline tidak merokok & 0,074 & 0,169 & 0,681 & 1,077 \\
\hline Konstan & $-0,373$ & 3,255 & 0,071 & 0,689 \\
\hline
\end{tabular}

Sumber: Susenas MKP 2019 (diolah)

Model regresi logistik biner dengan metode Maximum Likelihood Estimate (MLE) yang diperoleh untuk menggambarkan hubungan antara variabel independen terhadap status kesehatan balita di Nusa Tenggara Timur tahun 2019 adalah sebagai berikut.

$$
\begin{aligned}
\hat{g}(x)= & -0,373+0,372 D_{1}-0,258 D_{2}-0,245 D_{3}+0,881 D_{4}+0,280 D_{5}-0,045 D_{6}-0,174 D_{7} \\
& +0,074 D_{8}
\end{aligned}
$$

Hasil pengujian parsial untuk variabel umur balita diperoleh nilai $W=7,586>\chi_{(0,05 ; 1)}^{2}=3,841$ dan $p$ value $=0,006<0,05$. Oleh karena itu, keputusan yang diperoleh adalah tolak $\mathrm{H}_{0}$. Maka dapat disimpulkan bahwa pada tingkat signifikansi 5 persen variabel umur balita memiliki pengaruh yang signifikan terhadap status kesehatan balita. Hasil penelitian ini sesuai dengan temuan yang dihasilkan oleh Suanta (2016), Supraptini et al. (2010) serta Chen \& Li (2009). Namun, hasil penelitian ini berbeda dengan penelitian Oduro (2018) yang menyatakan bahwa umur bayi tidak signifikan mempengaruhi kesehatan balita.

Hasil pengujian parsial untuk variabel tingkat pendidikan ibu diperoleh nilai $W=3,200<\chi_{(0,05 ; 1)}^{2}=$ 3,841 dan $p$-value $=0,074>0,05$. Oleh karena itu, keputusan yang diperoleh adalah gagal tolak $\mathrm{H}_{0}$. Maka dapat disimpulkan bahwa pada tingkat signifikansi 5 persen variabel tingkat pendidikan ibu tidak memiliki pengaruh yang signifikan terhadap status kesehatan balita. Hasil penelitian ini tidak sesuai dengan penelitian sebelumnya yang dilakukan oleh Chen \& Li (2009), Lazuwardi (2020) dan Kiross et al. (2019). Namun, hasil penelitian ini sesuai dengan temuan Nusantari (2016) yang menyimpulkan bahwa tingkat pendidikan ibu tidak berpengaruh terhadap kesehatan bayi. Hal tersebut dikarenakan tingkat pendidikan yang ditamatkan oleh ibu dinilai kurang representatif dibandingkan dengan pengetahuan ibu tentang kesehatan dan perawatan keluarga untuk menggambarkan kesehatan pada bayi.

Hasil pengujian parsial untuk variabel status pekerjaan ibu diperoleh nilai $W=3,232<\chi_{(0,05 ; 1)}^{2}=$ 3,841 dan $p$-value $=0,072>0,05$. Oleh karena itu, keputusan yang diperoleh adalah gagal tolak $\mathrm{H}_{0}$. Maka dapat disimpulkan bahwa pada tingkat signifikansi 5 persen variabel status pekerjaan ibu tidak memiliki pengaruh yang signifikan terhadap status kesehatan balita. Hasil ini tidak sesuai dengan penelitian-penelitian sebelumnya, seperti penelitian Hong \& White-Means (1993), Akinyemi et al. (2018) dan Bickton et al. (2020). Hasil penelitian ini sejalan dengan hasil penelitian (Lazuwardi, 2020) yang menyimpulkan bahwa pekerjaan ibu tidak berpengaruh signifikan terhadap kesehatan bayi di Jawa Timur.

Hasil pengujian parsial untuk variabel kesehatan ibu diperoleh nilai $W=36,757>\chi_{(0,05 ; 1)}^{2}=3,841$ dan $p$-value $=0,000<0,05$. Oleh karena itu, keputusan yang diperoleh adalah tolak $\mathrm{H}_{0}$. Maka dapat disimpulkan bahwa pada tingkat signifikansi 5 persen variabel kesehatan ibu memiliki pengaruh yang signifikan terhadap status kesehatan balita. Hasil ini didukung oleh penelitian yang dilakukan oleh Hong \& White-Means (1993). Kesehatan ibu ditinjau dari segi psikis juga berpengaruh terhadap nutrisi dan penyakit yang dialami oleh bayi (Rahman et al., 2004). Kesehatan ibu juga berkorelasi kuat dengan kesehatan bayi serta mempengaruhi kelangsungan hidup bayi umur dibawah 5 tahun (Pandey, 2009).

Hasil pengujian parsial untuk variabel akses sanitasi diperoleh nilai $W=4,011>\chi_{(0,05 ; 1)}^{2}=3,841$ dan $p$-value $=0,045<0,05$. Oleh karena itu, keputusan yang diperoleh adalah tolak $\mathrm{H}_{0}$. Maka dapat disimpulkan 
bahwa pada tingkat signifikansi 5 persen variabel akses sanitasi memiliki pengaruh yang signifikan terhadap status kesehatan balita. Hasil ini sesuai dengan temuan Cheng et al. (2012) dan Suanta (2016). Nusantari (2016) juga menyimpulkan bahwa ketersediaan fasilitas BAB sebagai fasilitas sanitasi berpengaruh signifikan terhadap kesehatan bayi di Indonesia. Akses sanitasi merupakan faktor yang memiliki pengaruh yang sangat besar terhadap kesehatan bayi (Esrey et al., 1991).

Hasil pengujian parsial untuk variabel sumber air minum diperoleh nilai $W=0,098<\chi_{(0,05 ; 1)}^{2}=3,841$ dan $p$-value $=0,760>0,05$. Oleh karena itu, keputusan yang diperoleh adalah gagal tolak $\mathrm{H}_{0}$. Maka dapat disimpulkan bahwa variabel sumber air minum tidak memiliki pengaruh yang signifikan terhadap status kesehatan balita. Hasil penelitian ini tidak sesuai dengan temuan penelitian sebelumnya yang dilakukan oleh Nusantari (2016) dan Cheng et al. (2012) bahwa sumber air minum berpengaruh secara signifikan terhadap kesehatan bayi. Sementara itu, temuan Esrey et al. (1991) dan Susilo et al. (2020) mendukung hasil penelitian ini bahwa sumber air minum tidak mempengaruhi kesehatan bayi. Esrey et al. (1991) menemukan bahwa tidak ada hubungan antara sumber air minum dengan kesehatan. Selain itu, ditemukan pula bahwa kuantitas air yang dikonsumsi oleh rumah tangga dapat meningkatkan kesehatan dimana rumah tangga yang mengkonsumsi air minum yang lebih banyak akan lebih sehat dibandingkan dengan rumah tangga yang mengkonsumsi lebih sedikit. Hal ini kemudian didukung oleh temuan Susilo et al. (2020) bahwa beberapa daerah di Nusa Tenggara Timur dalam memenuhi kebutuhan akan air minum yang layak belum dapat mencukupi kebutuhan penduduk yang tiap tahun semakin meningkat, ditambah lagi akses dan distribusi air yang masih bermasalah.

Hasil pengujian parsial untuk variabel jenis lantai diperoleh nilai $W=1,094<\chi_{(0,05 ; 1)}^{2}=3,841$ dan $p$ value $=0,296>0,05$. Oleh karena itu, keputusan yang diperoleh adalah gagal tolak $\mathrm{H}_{0}$. Maka dapat disimpulkan bahwa variabel jenis lantai tidak memiliki pengaruh yang signifikan terhadap status kesehatan balita. Hasil ini tidak sesuai dengan penelitian terdahulu yang dilakukan oleh Suanta (2016) dan Supraptini et al. (2010) bahwa jenis lantai merupakan variabel yang berpengaruh secara signifikan terhadap kejadian sakit diare dan ISPA pada bayi. Hasil penelitian ini didukung oleh temuan Aprianawati (2018) menyimpulkan tidak ada hubungan yang bermakna antara jenis lantai dengan kejadian tuberkulosis pada anak. Jenis lantai juga tidak berpengaruh secara signifikan terhadap kesehatan bayi terkait kejadian difteri (Sari, 2012)

Hasil pengujian parsial untuk variabel kebiasaan merokok ART diperoleh nilai $W=0,169<\chi_{(0,05 ; 1)}^{2}$ $=3,841$ dan $p$-value $=0,681>0,05$. Oleh karena itu, keputusan yang diperoleh adalah gagal tolak $\mathrm{H}_{0}$. Maka dapat disimpulkan bahwa variabel kebiasaan merokok ART tidak memiliki pengaruh yang signifikan terhadap status kesehatan balita. Hasil penelitian ini tidak sesuai dengan teori dan penelitian-penelitian terdahulu. Budiati \& Duarsa (2012) dan Supraptini et al. (2010 menyimpulkan bahwa anggota rumah tangga yang merokok berpengaruh signifikan terhadap kesehatan bayi utamanya pada bagian pernapasan. Bayi sebagai perokok pasif dalam rumah tangganya sangat berisiko memiliki penyakit berbahaya pada sistem pernapasannya (Jones et al., 2011). Hasil penelitian ini didukung oleh penelitian Bickton et al. (2020).

\section{Pengujian Kesesuaian Model}

Uji kesesuaian model dilakukan untuk mengetahui apakah model yang terbentuk telah dapat menggambarkan secara tepat mengenai status kesehatan balita di provinsi Nusa Tenggara Timur tahun 2019.

Tabel 5. Hasil pengujian Hosmer \& Lemeshow

\begin{tabular}{ccc}
\hline Chi-square & df & p-value \\
\hline 7,380 & 8 & 0,496 \\
\hline
\end{tabular}

Sumber : Susenas MKP 2019 (diolah)

Pengujian dengan menggunakan uji Hosmer dan Lemeshow diperoleh nilai $\hat{C}=7,380$ dengan $p$-value $=$ 0,496 . Berdasarkan hasil tersebut nilai $\hat{C}=7,380<\chi^{2}{ }_{(0,05 ; 8)}=15,507$ dan $p$-value $=0,496>0,05$. Maka pengujian ini menghasilkan keputusan gagal tolak $\mathrm{H}_{0}$. Artinya, model yang terbentuk adalah model fit atau model telah menggambarkan status kesehatan balita di provinsi Nusa Tenggara Timur tahun 2019 secara tepat.

\section{Kecenderungan Status Kesehatan Balita di Nusa Tenggara Timur Tahun 2019}

\section{Umur Balita}

Koefisien $(\beta)$ dari variabel umur balita sebesar $-0,372$ dengan odds ratio sebesar 0,689 . Artinya bahwa balita di Nusa Tenggara Timur yang berumur lebih dari sama dengan dua tahun memiliki kecenderungan 0,689 kali untuk berstatus tidak sehat dibandingkan balita yang berumur kurang dari dua tahun dengan 
asumsi variabel independen lain bernilai konstan. Dengan demikian, balita yang berumur kurang dari dua tahun memiliki kecenderungan yang lebih besar untuk tidak sehat dibandingkan balita berumur lebih dari sama dengan dua tahun. Hasil ini sejalan dengan penelitian Suanta (2016) yang menyatakan bahwa balita berumur kurang dari dua tahun memiliki kecenderungan yang lebih besar untuk menderita diare dibandingkan dengan balita berumur lebih dari sama dengan dua tahun. Berdasarkan hasil Susenas 2019, proporsi bayi berusia kurang dari dua tahun di Provinsi Nusa Tenggara Timur yang menerima imunisasi lengkap hanya sebesar 58,30 persen. Dengan demikian, masih banyak bayi berusia kurang dari dua tahun yang mudah terserang berbagai penyakit. Sementara itu, penelitian Supraptini et al. (2010), Bickton et al. (2020) dan Chen \& Li (2009) menunjukkan peningkatan umur meningkatkan risiko kesehatan pada bayi.

\title{
Kesehatan Ibu
}

Koefisien $(\beta)$ dari variabel status pekerjaan ibu sebesar 0,881 dengan odds ratio sebesar 2,414 . Artinya bahwa balita di Nusa Tenggara Timur yang memiliki ibu yang tidak sehat memiliki kecenderungan 2,414 kali untuk berstatus tidak sehat dibandingkan balita yang memiliki ibu yang tidak sehat dengan asumsi variabel independen lain bernilai konstan. Hal tersebut menunjukkan bahwa balita dengan ibu yang tidak sehat memiliki kecenderungan yang lebih besar untuk tidak sehat dibandingkan balita dengan ibu sehat. Ibu yang tidak sehat secara psikis berdampak buruk pada kesehatan bayi, yaitu pertumbuhan yang buruk dan kecenderungan yang lebih besar untuk sakit dibandingkan dengan ibu yang sehat. Hal ini dikarenakan ibu yang tidak sehat cenderung memiliki gaya hidup yang tidak sehat, kurang memberikan perawatan pada masa perkembangan bayinya serta kurang memberikan sentuhan fisik, perhatian emosional dan stimulasi psikis pada bayinya (Rahman et al., 2004). Ibu yang sehat berdampak positif terhadap ketahanan hidup bayi (Pandey, 2009). Hasil berbeda diperoleh pada penelitian Hong \& White-Means (1993) yang menunjukkan bahwa kesehatan ibu berdampak negatif terhadap kesehatan anaknya. Dimana ibu yang sehat cenderung memiliki anak dengan kesehatan yang buruk.

\begin{abstract}
Akses Sanitasi
Koefisien $(\beta)$ dari variabel akses air minum sebesar 0,280 dengan odds ratio sebesar 1,323. Artinya bahwa balita di Nusa Tenggara Timur yang tinggal di tempat tinggal dengan akses sanitasi tidak layak memiliki kecenderungan 1,323 kali untuk berstatus tidak sehat dibandingkan balita yang tinggal di tempat tinggal dengan akses sanitasi layak dengan asumsi variabel independen lain bernilai konstan. Hasil tersebut menunjukkan bahwa balita dengan akses sanitasi tidak layak memiliki kecenderungan yang lebih besar untuk tidak sehat dibandingkan dengan bayi yang tinggal dengan akses sanitasi layak. Hasil penelitian ini didukung oleh penelitian-penelitian terdahulu. Kasnodihardjo \& Elsi (2013) mengatakan bahwa sanitasi yang buruk merupakan penyebab terbesar penyakit diare yang dialami oleh bayi. Esrey et al. (1991) juga menyimpulkan bahwa akses sanitasi memiliki pengaruh yang sangat besar terhadap kesehatan bayi, dimana peningkatan kualitas pada akses sanitasi mampu menurunkan secara signifikan indikator-indikator kesehatan bayi, seperti angka kematian bayi dan angka morbiditas bayi. Penelitian Cheng et al. (2012) menunjukkan bahwa peningkatan kualitas sanitasi secara signifikan berpengaruh secara positif terhadap kesehatan bayi. Besarnya risiko akses sanitasi yang tidak layak terhadap kesehatan bayi dikarenakan akses sanitasi yang layak mampu mengurangi kontaminasi dan penularan bakteri dan kotoran yang terdapat pada fasilitas sanitasi (Nusantari, 2016).
\end{abstract}

\section{KESIMPULAN}

Persentase balita berstatus tidak sehat di Nusa Tenggara Timur tahun 2019 sebesar 50,31 persen. Pada tingkat signifikansi 5 persen, variabel umur balita, kesehatan ibu dan akses sanitasi secara signifikan mempengaruhi status kesehatan balita di Provinsi Nusa Tenggara Timur tahun 2019. Lima variabel lainnya, yaitu tingkat pendidikan ibu, status pekerjaan ibu, sumber air minum, jenis lantai dan kebiasaan merokok ART tidak signifikan mempengaruhi status kesehatan balita di Provinsi Nusa Tenggara Timur tahun 2019. Balita dengan karakteristik berusia kurang dari dua tahun yang memiliki ibu tidak sehat serta memiliki tempat tinggal dengan akses sanitasi yang tidak layak memiliki kecenderungan yang lebih besar untuk tidak sehat.

\section{DAFTAR PUSTAKA}

Akinyemi, J. O., Solanke, B. L., \& Odimegwu, C. O. (2018). Maternal employment and child survival during the era of sustainable development goals: Insights from proportional hazards modelling of Nigeria birth history data. Annals of Global Health, 84(1), 15-30. 
Aprianawati, E. (2018). Hubungan Kondisi Fisik Rumah Terhadap Kejadian Tuberkolosis di Wilayah Kerja Puskesmas Gantrung Kabupaten Madiun [Skripsi]. Madiun: Stikes Bhakti Husada Mulia Madiun.

Badan Pusat Statistik. (2018). Profil Kesehatan Ibu dan Anak 2018. Jakarta: Badan Pusat Statistik.

(2019). Indikator Tujuan Pembangunan Berkelanjutan (TPB) Indonesia 2019.

Jakarta: Badan Pusat Statistik. . (2019). Profil Statistik Kesehatan 2019. Jakarta: Badan Pusat Statistik.

Behrman, Kliegman, \& Arvin. (1999). Ilmu Kesehatan Anak. Jakarta: Penerbit Buku Kedokteran EGC.

Bickton, F. M., Ndeketa, L., Sibande, G. T., Nkeramahame, J., Payesa, C., \& Milanzi, E. B. (2020). Household air pollution and under-five mortality in sub-Saharan Africa: an analysis of 14 demographic and health surveys. Environmental Health and Preventive Medicine, 25(1), 1-11.

Budiati, E., \& Duarsa, A. B. S. (2012). Kondisi Rumah dan Pencemaran Udara Dalam Rumah Sebagai Faktor Risiko Kejadian Pneumonia Balita. Jurnal Kedokteran Yarsi, 20(2), 87-101.

Chen, Y., \& Li, H. (2009). Mother's education and child health: Is there a nurturing effect? Journal of Health Economics, 28(2), 413-426.

Cheng, J. J., Schuster-Wallace, C. J., Watt, S., Newbold, B. K., \& Mente, A. (2012). An ecological quantification of the relationships between water, sanitation and infant, child, and maternal mortality. Environmental Health: A Global Access Science Source, 11(1), 1-8.

Eliana, \& Sumiati, S. (2016). Kesehatan Masyarakat. Jakarta: Kementerian Kesehatan RI.

Esrey, S. A., Potash, J. B., Roberts, L., \& Shiff, C. (1991). Effects of improved water supply and sanitation on ascariasis, diarrhoea, dracunculiasis, hookworm infection, schistosomiasis, and trachoma. Bulletin of the World Health Organization, 69(5), 609-621.

Fitriyani, Y., Roosita, K., \& Effendi, Y. H. (2008). Kondisi Lingkungan, Perilaku Hidup Sehat, Dan Status Kesehatan Keluarga Wanita Pemetik Teh. Jurnal Gizi Dan Pangan, 3(2), 86-93.

Hong, G. S., \& White-Means, S. I. (1993). Do working mothers have healthy children? Journal of Family and Economic Issues, 14(2), 163-186.

Hosmer, D. W., Lemeshow, S., \& Sturdivant, R. X. (2013). Applied Logistic Regression : Third Edition. New Jersey: John Wiley \& Son.

Jones, L. L., Hashim, A., McKeever, T., Cook, D. G., Britton, J., \& Leonardi-Bee, J. (2011). Parental and household smoking and the increased risk of bronchitis, bronchiolitis and other lower respiratory infections in infancy: Systematic review and meta-analysis. Respiratory Research, 12, 1-11.

Kasnodihardjo, K., \& Elsi, E. (2013). Deskripsi Sanitasi Lingkungan, Perilaku Ibu, dan Kesehatan Anak. Kesmas: National Public Health Journal, 7(9), 415.

Kementerian Kesehatan RI. (2019). Laporan Nasional Riskesdas 2018. Jakarta: Kementerian Kesehatan RI.

Kiross, G. T., Chojenta, C., Barker, D., Tiruye, T. Y., \& Loxton, D. (2019). The effect of maternal education on infant mortality in Ethiopia: A systematic review and meta-analysis. PLoS ONE, 14(7), 1-12.

Lazuwardi, B. (2020). Logistics Regression Modeling on Infant Mortality Rates in East Java Province. The Indonesian Journal of Public Health, 15(2), 146-152.

Notoatmodjo, S. (2008). Kesehatan dan Pembangunan Sumber Daya Manusia. Kesmas: National Public Health Journal, 2(5), 195-199.

Nusantari, R. A. (2016). Faktor-Faktor Yang Mempengaruhi Keluhan Kesehatan Baduta Rumah Tangga Miskin Di Indonesia Tahun 2013 [skripsi]. Jakarta: Sekolah Tinggi Ilmu Statistik.

Oduro, F. T. (2018). Logistic Regression Model on Infant Mortality at the Komfo Anokye Teaching Hospital, Kumasi - Ghana. 7(3), 63-66.

Pandey, M. K. (2009). Maternal Health and Child Mortality in Rural India. ASARC Working Paper 2009/12.

Rahman, A., Iqbal, Z., Bunn, J., Lovel, H., \& Harrington, R. (2004). Impact of maternal depression on infant nutritional status and illness: A cohort study. Archives of General Psychiatry, 61(9), 946-952.

Riyadi, A. L. (2016). Ilmu Kesehatan Masyarakat. Yogyakarta: Andi Offset.

Sari, P. M. (2012). Pengaruh Kondisi Sanitasi Rumah, Status Imunisasi dan Pengetahuan Ibu. Swara Bhumi e-Journal, 1(2),1-7.

Shahraki, M., Agheli, L., Assari Arani, A., \& Sadeghi, H. (2016). The Effect of Mothers' Education and Employment on Children's Health. Jentashapir Journal of Health Research, 7(4), 1-7.

Siswanto, H. (2012). Pendidikan Kesehatan Unsur Utama dalam Pendidikan Anak Usia Dini. Cakrawala Pendidikan, 1(1), 305-322.

Suanta, M. (2016). Pengaruh Sanitasi Lingkungan Tempat Tinggal Dan Karakteristik Sosial Ekonomi Rumah Tangga Terhadap Terjadinya Diare Pada Balita Di Nusa Tenggara Timur (Analisis Lanjut Data Susenas 2012). Bumi Lestari Journal of Environment, 16(2), 119-130. 
Supraptini, Hanato, M. \& Hapsari, D. (2010). Faktor-faktor pencemaran udara dalam rumah yang berhubungan dengan kejadian ISPA pada balita di Indonesia. Jurnal Ekologi Kesehatan. 9(2). 12381247.

Susilo, A., Vidyattama, Y., \& Eva Wishanti, D. A. P. (2020). Water and sanitation program in decentralised eastern Indonesia: The roles of community and social dynamics. Australasian Journal of Regional Studies, 26(1), 77-106.

Undang-Undang Republik Indonesia Nomor 36 Tahun 2009 Tentang Kesehatan. 